\title{
CAMBRIAN - MIDDLE ORDOVICIAN STRATIGRAPHY OF THE ADAMS GLETSCHER REGION, SOUTH-WEST PEARY LAND, NORTH GREENLAND
}

\author{
John S. Peel
}

Previous geological descriptions of the Adams Gletscher region (fig. 9) have been given by J. C. Troelsen (unpublished field notes in GGU) and Dawes (1976) - the latter based on a three day reconnaissance during 1975 . The sequence contains a much fuller record of the Cambrian system than is present in the geologically better described area near Jørgen Brønlund Fjord to the east (Christie \& Peel, 1977; Jepsen, 1971), where only Lower Cambrian strata are present. A sample with trilobites collected by Dawes established the occurrence of Middle Cambrian rocks near Adams Gletscher (Peel in Dawes, 1976), but it would now appear that a substantial part of the sequence is of this age. In addition, the location in 1978 of early Late Cambrian trilobites near the base of a $900 \mathrm{~m}$ thick unit overlain by the Wandel Valley Formation of Early-Middle Ordovician age, suggests that the upper sub-division of the Cambrian is also well represented.

An unconformity of regional extent separates the Cambrian from the overlying Wandel Valley Formation. This formation maintains the same general lithology at Adams Gletscher as that described by Christie \& Peel (1977) to the east, although a tentative lithological link to the late Lower Ordovician of western North Greenland is established.

\section{Stratigraphy}

A general stratigraphic scheme is presented in fig. 10, together with approximate correlations to the Jørgen Brønlund Fjord area. Two new stratigraphic groups, the Brønlund Fjord Group and the Tavsens Iskappe Group, are formally proposed and sub-divided into formations, although the formations are not named at this time.

Strata on both sides of Adams Gletscher generally dip at about 5-8 to the north, although the Cambrian beneath the unconformity with overlying Wandel Valley Formation is shallowly flexured with dips locally reaching a maximum of $20^{\circ}$ to the north (fig. 9, locality 2 ). Several prominent, approximately east-west normal faults are conspicuous, the largest of which occurs between localities 5 and 6 and was noted previously by Dawes (1976) who calculated a downthrow on the southern side of 800-1000 m (see map 1). Thin, north-south trending basic dykes on both sides of the glacier often show slight vertical displacement along the plane of intrusion. 


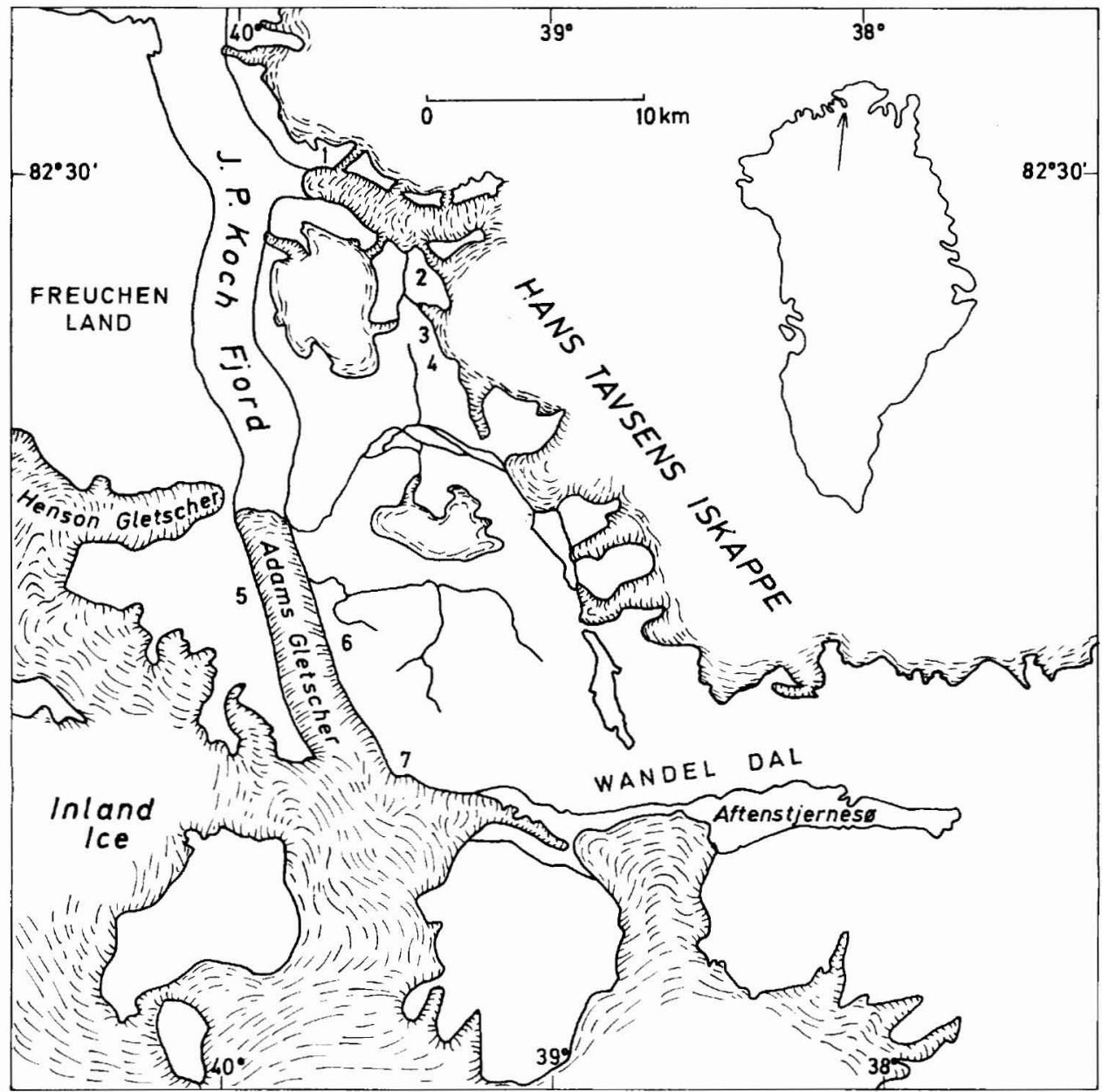

Fig. 9. The Adams Gletscher region. Numbers refer to localities mentioned in the text.

\section{Portfjeld Formation}

The Portfjeld Formation (Jepsen, 1971) is the oldest rock unit exposed in the Adams Gletscher - J. P. Koch Fjord region, with reddish brown weathering dolomites and sandstone outcropping along the foot of the cliffs on both sides of the major fault (fig. 9, locality 6). About $180 \mathrm{~m}$ of strata are exposed (locality 5) and can be tentatively correlated with the type sequence at Portfjeld, to the east. Of notable interest is the change in character of Jepsen's bed 18, a $5 \mathrm{~m}$ thick orthoquartzite, which at Adams Gletscher consists of at least $20 \mathrm{~m}$ of dark, cross-bedded, coarse-grained, conglomeratic sandstone (see also discussion by O'Connor, this report). Outcrops are frequently yellow, green or orange stained and joints in the measured section were filled with white gypsum(?) and bright yellow sulphur. The 
boundary of the Portfjeld Formation with the overlying basal sandstone of the Buen Formation is apparently rather sharp. No fossil remains other than stromatolites were found.

It is relatively simple to recognise the equivalence between unit $A(180 \mathrm{~m})$ of Dawes (1976) and the Portfjeld Formation section of similar thickness measured in 1978 on the opposite side of Adams Gletscher. The rusty weathering, coarse-grained sandstone is common to both units, as also is the underlying dolomite breccia.

\section{Buen Formation}

A single section about $375 \mathrm{~m}$ in thickness was measured through the Buen Formation (Jepsen, 1971) immediately west of Adams Gletscher (fig. 9, locality 5), but local faulting

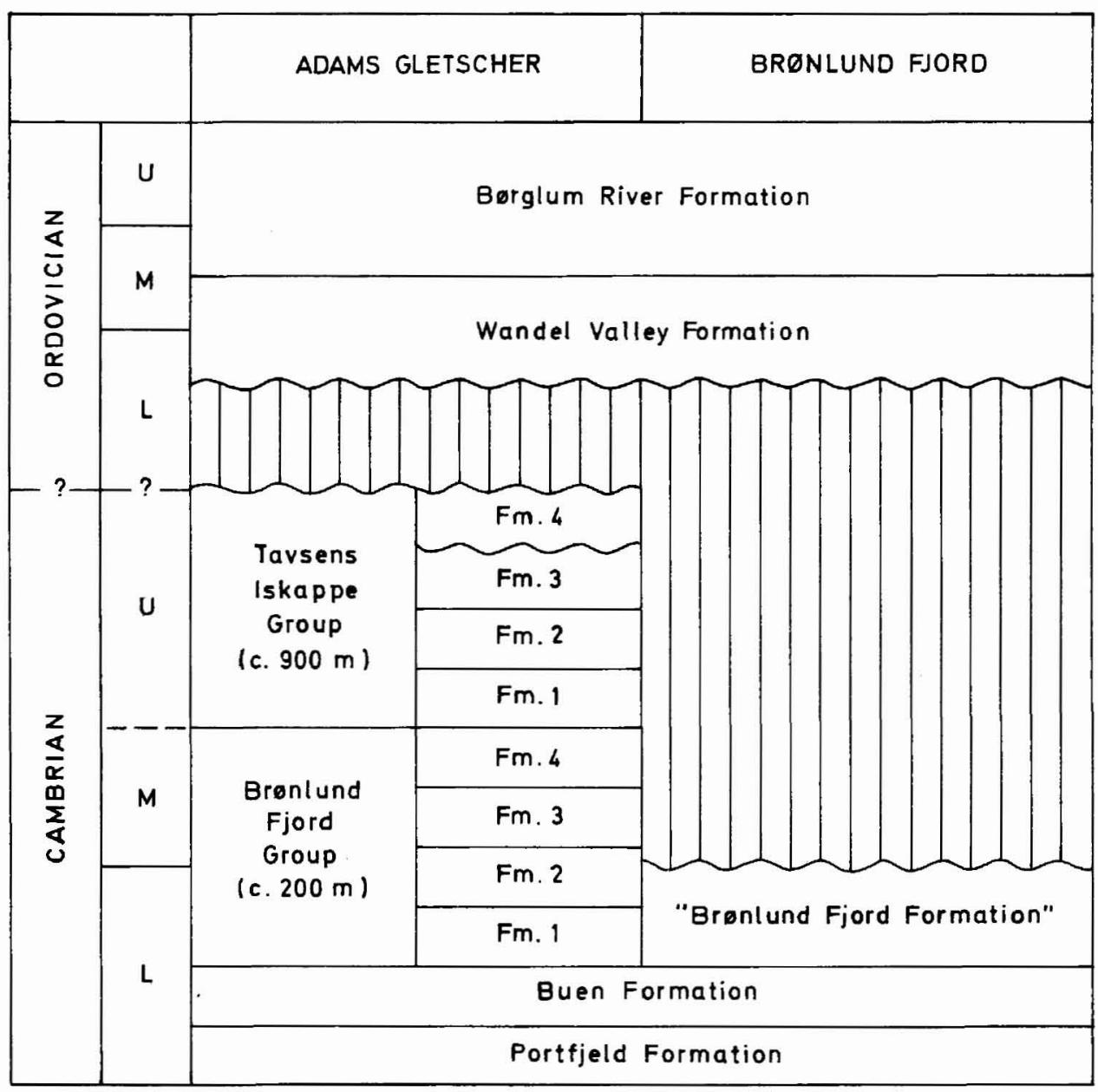

Fig. 10. Cambrian - Ordovician sequence at Adams Gletscher, compared to the Jørgen Brønlund Fjord region. 
has probably duplicated about $50 \mathrm{~m}$ of the largely talus covered sequence. The lowest $155 \mathrm{~m}$ of the formation is mainly composed of fine to medium grained, dark, micaceous, often glauconitic, laminated and thin-bedded sandstones with interbedded silts. Cross-beddding, ripple marks, sedimentary and organic bottom structures, and general bioturbation are common. A distinctive reddish weathering, massive, medium-coarse grained sandstone about $25 \mathrm{~m}$ in thickness occurs at the base of the formation. A similar, but thinner $(10 \mathrm{~m})$ sandstone about $115 \mathrm{~m}$ above the base of the formation is conglomeratic in the lowest $1 \mathrm{~m}$, with flat-lying siltstone slabs up to $30 \mathrm{~cm}$ in diameter, and contains scattered glauconite. The two reddish weathering sandstones form benches which can be traced eastwards at least as far as Øvre Midsommersø.

The uppermost $200 \mathrm{~m}$ of the Buen Formation section, equivalent to perhaps $150 \mathrm{~m}$ of true thickness, is generally poorly exposed and recessive in weathering character. Fissile dark shales and thin siltstones outcrop in small deeply-weathered patches and appear to be the dominant lithologies. Rare, fragmentary olenellid trilobites indicative of an Early Cambrian age occur but the richly fossiliferous horizons known from outcrops in the Jørgen Brønlund Fjord area (Christie \& Peel, 1977) were not located during 1978.

Jepsen (1971) measured the thickness of the Buen Formation in its type section to $425 \mathrm{~m}$, and noted that the formation thinned towards the west. The $325-375 \mathrm{~m}$ thickness measured at Adams Gletscher seems to confirm his observation.

Units B, C and part of D of Dawes (1976) are tentatively equated with the Buen Formation as employed here. Unit C, c. $15 \mathrm{~m}$ of reddish weathering sandstone forming a bench between two reccessive intervals (units $B$ and $D$ ), seems to be recognisable as the upper of the two sandstone benches discussed above. Unit $B$ is considered equivalent to the interval of thinly bedded, dark sandstones between the two prominent sandstone benches. The lower part of unit $\mathrm{D}$ is correlated with the mainly shale and siltstone, recessive interval forming the upper part of the Buen Formation. However, due to miscorrelation between his section near locality 7 and the area around locality 5, Dawes included formations 1-4 of the Brønlund Fjord Group within his unit D. Thus, unit E of Dawes and the upper part of Unit D are equivalent.

\section{Name and history}

\section{Brønlund Fjord Group}

new group

From Jørgen Brønlund Fjord, Peary Land. The Brønlund Fjord Group includes, but is not exactly equivalent to, strata previously referred to the Brønlund Fjord Formation (Troelsen, 1949; Christie \& Peel, 1977) in its type area north of Jørgen Brønlund Fjord. The Brønlund Fjord Formation is no longer recognised as a lithostratigraphic unit at the rank of formation; strata in the type section originally assigned to this formation are correlated with the two lowest new formations in the Adams Gletscher reference sequence. The Brønlund Fjord Group includes units E and F of Dawes (1976) described from the group's type area.

\section{Type area}

The type area of the Brønlund Fjord Formation, and hence the group, is on the north side of Jørgen Brønlund Fjord (Troelsen, 1949, Christie \& Peel, 1977). However, the sequence 
here is incomplete due to overstep by the Wandel Valley Formation. Hence, a reference section in which the Group is fully developed is established immediately west of Adams Gletscher (fig. 9, locality 5).

\section{Lithology and distribution}

In the reference area, the Brønlund Fjord Group is a varied sequence $(c .200 \mathrm{~m})$ of pale dolomites, including breccias and pseudobreccias, dark cherty dolomites, and interbedded limestones and shales. In more southerly and easterly outcrops overlooking Wandel Dal, the limestones, shales and darker dolomites give way to sandy dolomite and quartz sandstones.

Strata assigned to the group can be traced in more or less continuous outcrop from Freuchen Land, in the west, across southern Peary Land to Independence Fjord, in the east.

\section{Boundaries and subdivision}

The Brønlund Fjord Group is subdivided into 4 formations described below in ascending order, but these are not formally proposed at this time. The group overlies the Buen Formation with apparent conformity and is itself conformably overlain by the Tavsens Iskappe Group, described below. To the east of the Adams Gletscher area, dolomites of the Wandel Valley Formation (Early-Middle Ordovician) progressively overstep the Tavsens Iskappe Group and upper beds of the Brønlund Fjord Group until, at Jørgen Brønlund Fjord, the Wandel Valley Formation lies without discernible angular discordance (Troelsen, 1949; Christie \& Peel, 1977) upon lower formations of the Brønlund Fjord Group.

\section{Geological age}

Early-Middle Cambrian.

\section{Formation 1}

This formation, the basal unit of the Brønlund Fjord Group, is mainly composed of cliff-forming dolomites which appear pale weathering when viewed from a distance. A richly fossiliferous lower member (c. $3 \mathrm{~m}$ ), member A of the Brønlund Fjord Formation of Christie \& Peel (1977), can be traced from Adams Gletscher to Jørgen Brønlund Fjord, in the east. The remaining, approximately $60 \mathrm{~m}$ of the formation are composed of a variety of dolomites, with dolomite breccias, nodular, laminated and bioturbated dolomites, with or without cherts, forming conspicuous elements. With the exception of rich Early Cambrian faunas from the lower member, formation 1 has not yielded fossils.

Dawes (1976) included the present formation 1 within unit $E$, which he measured near locality 7 in fig. 9 and correlated with the Brønlund Fjord Formation. Unit $E$ is here divided into three formations (formations 1-3), of which the present formation corresponds to the "basal sub-unit of yellow weathering, massive looking, dolomite and dolomite breccia" of Dawes. 


\section{Formation 2}

In contrast to underlying and overlying, pale weathering, cliff-forming units, this formation is typically dark weathering and recessive. Sooty weathering, finely laminated, bituminous dolomites with subsidiary shales and limestones are characteristic, but thin, pale weathering beds of dolomitic sandstone become more conspicuous in more southerly outcrops. Cherts are widespread, as are $40-75 \mathrm{~cm}$ wide bullions of finely laminated dolomite or limestone. The formation attains a thickness of about $70 \mathrm{~m}$ near Henson Gletscher (locality 5) but thins to about half this thickness within $15 \mathrm{~km}$ to the north (locality 4 ), and also $10 \mathrm{~km}$ to the south (locality 7). Formation 2 has yielded a rich fauna of Early-Middle Cambrian age. Trilobites dominate, but brachiopods and molluscs are well represented.

Formation 2 is equivalent to the middle sub-unit of unit $E$ of Dawes (1976). His description of "a seemingly thinner bedded, banded sub-unit" reflects the increased abundance of the thin, pale weathering dolomitic sandstones in more southerly outcrops.

\section{Formation 3}

The cliff-forming dolomites of this formation weather pale in contrast to the dark, recessive units above and below. The dominant lithology near Henson Gletscher (fig. 9, locality 5) appears to be a wavy or lenticular laminated 'heterolith' of pale and dark dolomite, with irregular chert nodules and drusy dolomite vugs. Spherical patches up to $5 \mathrm{~cm}$, rarely $25 \mathrm{~cm}$, of coarse, radiating crystals of calcite are characteristic of many outcrops. At locality 7 the formation consists of about $40 \mathrm{~m}$ of thin bedded, sugary dolomites with $4 \mathrm{~m}$ of pale weathering dolomite breccia near the top. About $20 \mathrm{~km}$ to the north (locality 4), this thickness is reduced to only $8 \mathrm{~m}$. Formation 3 is generally unfossiliferous but phosphatic tubes of Hyolithellus type and inarticulate brachiopods (cf. Linnarssonia) may be quite common at locality 7.

This is the same fauna identified by myself in Dawes (1976) which, on account of the occurrence of both fossils in the Early Cambrian member A of the Brønlund Fjord Formation (Christie \& Peel, 1977) was also considered to be Early Cambrian. The age assignment is clearly no longer correct since underlying beds in formation 2 contain Middle Cambrian trilobites. Overlying beds of formation 4 also yield Middle Cambrian faunas, demonstrating a similar age for formation 3. Dawes (1976) referred to strata placed within formation 3 as the upper sub-unit of his unit E. His correlation of the sub-unit with part of the Brønlund Fjord Formation at Jørgen Brønlund Fjord is no longer accepted.

\section{Formation 4}

Formation 4 tends to be grey weathering and recessive in outcrops along Adams Gletscher and J. P. Koch Fjord in contrast to the paler, cliff-forming units above and below. About 85 $\mathrm{m}$ of soft grey shales and interbedded lenticular limestones were measured at locality 5 , near Henson Gletscher (fig. 9). As with formations 2 and 3 below, this thickness is reduced by half at locality 4 . To the south (locality 7), the upper two thirds of the formation are composed of thinly bedded, grey dolomite with some dolomite breccia. Rich faunas are characteristic of much of this formation and indicate a general Middle Cambrian age. 
Strata assigned by Dawes (1976) to unit F are included within formation 4, although the lithology described by Dawes (locality 7 ) is not representative of the formation as a whole.

\section{Tavsens Iskappe Group}

new group

\section{Name and history}

From Hans Tavsens Iskappe, western Peary Land. The group includes strata referred to unit $G$ by Dawes (1976) from the area around locality 7 in fig. 9.

\section{Type area}

On the western side of Hans Tavsens Iskappe, where the constituent rock units are excellently exposed along J. P. Koch Fjord and Adams Gletscher (principal measured sections, fig. 9, localities 3,4 ).

\section{Lithology and distribution}

The Tavsens Iskappe Group comprises a varied sequence $(c .900 \mathrm{~m})$ of dolomites, with minor limestones and sandstones. A dolomitised oolite recognised by Dawes (1976) is prominent in southern outcrops; pale weathering dolomite breccias, darker mottled and lenticular laminated dolomites, and black limy dolomite are also conspicuous.

The Tavsens Iskappe Group outcrops extensively around the south-east margins of Hans Tavsens Iskappe, generally forming higher ground. Outcrops extend westward into Freuchen Land and eastward, in Peary Land, to Øvre Midsommersø.

\section{Boundaries and subdivision}

The Tavsens Iskappe Group overlies the Brønlund Fjord Group without apparent angular discordance. The upper boundary of the group is marked by an erosion surface generally overlain by the Wandel Valley Formation of Early Ordovician age. Maximum development of the Tavsens Iskappe Group occurs in the type area, to the west of the Iskappe. Toward the south and south-east the group is progressively overstepped by the Wandel Valley Formation. No strata correlative with the Tavsens Iskappe Group occur within the Brønlund Fjord Formation of previous usage (Christie \& Peel, 1977) at Jørgen Brønlund Fjord - at this locality the Wandel Valley Formation sits without perceptible discordance on lower beds of the Brønlund Fjord Group.

Four formations are tentatively recognised within the Tavsens Iskappe Group in its type area, but these are not formally described at present. Rather different sequences are present to the south (the type sequence of Dawes' unit G), and to the east of Hans Tavsens Iskappe. A satisfactory correlation to these areas is not yet established. 


\section{Geological age}

Fossils are currently known only from formation 2, discussed below, where trilobites of early Late Cambrian age (Dresbachian) have been identified. The group is tentatively assumed to be entirely of Late Cambrian age, although basal beds could be latest Middle Cambrian and higher units could extend into the earliest Ordovician (early Canadian). The succeeding, unconformable, Wandel Valley Formation yields late Canadian fossils from its lower beds (Yochelson \& Peel, 1975; Christie \& Peel, 1977).

\section{Formation 1}

This unit comprises about $100 \mathrm{~m}$ of cliff-forming, pale weathering dolomite. Breccia dominates, often with a high degree of recrystallisation of the clasts, or the matrix between clasts. Other lithologies include strongly recrystallised laminated dolomites, with spar filled vugs, and mottled dolomite. The base of the unit was examined on the western side of Adams Gletscher, a few kilometres south of Henson Gletscher (locality 5), where dolomite breccia lies with a sharp base on the underlying nodular limestones of formation 4 of the Brønlund Fjord Group. The upper surface seems to have a shallowly undulating character (locality 3 ). Formation 1 possibly correlates with the oolite described by Dawes (1976) from unit $\mathrm{G}$ at locality 7 .

\section{Formation 2}

This formation is apparently about $170 \mathrm{~m}$ thick, although the upper $c .40$ per cent was not exposed in measured sections at locality 3 . The lower, remaining part is mainly dark, recessive, wavy or parallel bedded, laminated dolomitic limestone. A prominent bench forming the top of the exposed part of the formation is formed by $3 \mathrm{~m}$ of pale weathering dolomite breccia. Rich trilobite faunas have been collected from just above the base, and near the middle of the formation. The trilobites are of early Dresbachian (earliest Late Cambrian) age. Dr. A. R. Palmer (Stony Brook, personal communication, 1978) has identified species of Cedaria, Blountia, Kormagnostus and Oidalagnostus. As formation 2 is traced to the south in the inaccessible bluffs west of the head of J. P. Koch Fjord, the dark recessive beds are gradually replaced by pale, brownish weathering supposed dolomites which cannot be readily distinguished from underlying and overlying units. In the sequence examined at locality 7 well bedded and mottled, darker weathering dolomites overlying the very pale weathering basal oolite may be equivalent to formation 2, although confirmatory fossil evidence is lacking.

\section{Formation 3}

This formation is very imperfectly known, at this time, with only the lowest beds having being examined in the field (locality 3 ). A thickness of perhaps $100 \mathrm{~m}$ is preserved, of which the lowest $15-20 \mathrm{~m}$ is largely composed of pale weathering dolomite breccia. Weathering colours of higher, inaccessible strata suggest that similar dolomites make up much of the remaining thickness of the unit. The formation seems to conformably overlie formation 2 , 
although the junction is difficult of access or talus covered. The upper surface of formation 3 is marked by an unconformity which, in the type area of the Tavsens Iskappe Group (localities 2,3), dips shallowly to the north and gradually cuts out the formation. No fossils have been recovered from formation 3, a Late Cambrian age is presumed on account of the early Late Cambrian faunas of formation 2.

\section{Formation 4}

Formation 4 includes about $500-600 \mathrm{~m}$ of various pale-weathering dolomites, sandy dolomites and sandstones, although dark brown weathering, thinly bedded dolomites occur near the top. The formation unconformably overlies earlier formations of the Tavsens Iskappe Group. In the type area (localities 2, 3), to the west of Hans Tavsens Iskappe, the angular discordance between formation 4 and the overlying Wandel Valley Formation reaches a maximum of about 15 degrees, but a much lower angle of discordance separates formation 4 from the earlier units. Formation 4 is well exposed, but totally inaccessible in the vertical cliffs near the head of J. P. Koch Fjord. It is not at this time recognised outside the region of the type section, west of Hans Tavsens Iskappe. However, only a tenuous correlation has yet been established between sections in the Tavsens Iskappe Group on the western and eastern sides of the Iskappe.

Formation 4 has failed to yield macrofossils other than trace fossils. Its stratigraphic position between early Late Cambrian beds (formation 2) below, and the late Early Ordovician Wandel Valley Formation, above, indicates a Late Cambrian to (possibly) earliest Ordovician age, although the former is considered more likely.

\section{Wandel Valley Formation}

The Wandel Valley Formation (Troelsen, 1949; Christie \& Peel, 1977) of Early - early Middle Ordovician age outcrops extensively in southern Peary Land, capping most sections in the Adams Gletscher region. A thickness of about $260 \mathrm{~m}$ was measured on the eastern side of the glacier (fig. 9, locality 6), without reaching the top of the formation. J. M. Hurst (GGU, personal communication) noted a total thickness of between 450 and $500 \mathrm{~m}$ at locality 1.

The unit is lithologically very similar to the description given by Christie \& Peel (1977) in the Jørgen Brønlund Fjord region, although the well-marked subdivision into three members achieved in that area is not so evident at Adams Gletscher. Of note within the generally pale-weathering dolomite sequence is a $1 \mathrm{~m}$ thick bed of fine grey limestone with bathyurid trilobites which occurs about $60 \mathrm{~m}$ above the base. The lithology and fauna is very reminiscent of the Nunatami Formation of Washington Land, western North Greenland, of similar age - correlation between the Nunatami Formation and the lower Wandel Valley Formation is increased by the presence in both formations of Ceratopea unguis.

At locality 6, the Wandel Valley Formation rests on a gently billowing surface of dolomite and sandstone breccia of the Tavsens Iskappe Group. At locality $2,15^{\circ}$ of angular discordance separates the two units, although in most other localities in southern Peary Land the unconformity is not marked by perceptible angular discordance. 


\section{The Wandel Valley Formation basal unconformity}

The unconformity at the base of the Wandel Valley Formation is the principal structural feature within the Cambro-Ordovician platform sequence in southern Peary Land. Angular discordance between beds above and below the unconformity is rarely discernible on outcrop, although locally steepened dips in the Cambrian west of Hans Tavsens Iskappe produce a divergence of about $15^{\circ}$ at locality 2 . However, within southern Peary Land, the discordance is sufficient to cause the Wandel Valley Formation to overstep $1000 \mathrm{~m}$ of Late, Middle and possibly Early Cambrian from north-west to more south-easterly outcrops in an effective distance of about $40 \mathrm{~km}$ across the regional strike.

The significance of this overstep is evident when considering the lithological correlation suggested by O'Connor (this report) between the lower part of the Portfjeld Formation and the Danmarks Fjord Formation exposed near the head of Danmark Fjord (Cowie, 1971) The Danmarks Fjord Formation (10-30 m) is overlain by the Amdrup Formation of Late Canadian age - probably the Wandel Valley Formation of Peary Land usage - and has generally been correlated with the Brønlund Fjord Formation by most previous workers. However, Poulsen (1978) proposed an alternative correlation with the upper Portfjeld Formation and the lower Buen Formation.

In view of the $200 \mathrm{~km}$ from Jørgen Brønlund Fjord to the head of Danmark Fjord, to the south-east, there is little difficulty in envisaging that the Wandel Valley Formation could have progressively overstepped the Brønlund Fjord Group, the Buen Formation and the upper Portfjeld Formation to lie unconformably on the lower Portfjeld Formation - the Danmarks Fjord Formation sensu Cowie (1971). As stressed by O'Connor (this report), the correlation between the Portfjeld Formation and the Danmarks Fjord Formation is only a tentative suggestion, and further study is required. However, overstep by the Wandel Valley Formation provides a mechanism which could effectively explain such a correlation.

By correlation of sections from Adams Gletscher eastward along Wandel Dal to Øvre Midsommersø, Sæterdal and Jørgen Brønlund Fjord, it can be demonstrated that the Brønlund Fjord Formation of previous usage (Troelsen, 1949; Cowie, 1971; Christie \& Peel, 1977 ) is exclusively of Early Cambrian age. This has been surmised previously by most authors, although the only known fauna from the formation occurs a few metres above the base. Thus, at Jørgen Brønlund Fjord, rocks corresponding to a time interval Middle and Late Cambrian, to Early Canadian (early Early Ordocivian) have been eroded prior to deposition of the undoubtedly Late Canadian (late Early Ordovician) Wandel Vally Formation. At Adams Gletscher, at most, part of the Late Cambrian and the Early Canadian are missing, while the presence of about $800 \mathrm{~m}$ of strata between the youngest pre-unconformity fossils (Tavsens Iskappe Group, formation 2) and the Wandel Vally Formation suggests that the unconformity represents a still much shorter time interval.

\section{Economic Geology}

A small 'solfatara' of the type described by Troelsen (1949) from Jørgen Brønlund Fjord, with bright yellow sulphur, white gypsum (?), and reddish brown iron compounds, was observed at locality 5 on the upper surface of the Portfjeld Formation. Similar minerals fill joints in the conglomeratic sandstone in the Portfjeld Formation below. The sandstone at 
this locality is atypically dark in colour and apparently bituminous. The 'solfataras' have been thought to be associated with east-west trending faults (Dawes \& Peel, in press). However, in the context of the Adams Gletscher occurrence, derivation from hydrocarbons within the Portfjeld Formation is possible.

Other features within the area of interest to petroleum prospecting include possible source rocks (shales of the Buen Formation, and dark shaly dolomites of formation 2, Brønlund Fjord Group), and a potential for traps associated with the sub-Wandel Vally Formation unconformity and associated east-west trending faults. Potential reservoir rocks include the Portfjeld Formation sandstone, but the widespread vuggy texture in the Cambrian dolomites lacks obvious interconnection.

\section{References}

Christie, R. L. \& Peel, J. S. 1977: Cambrian-Silurian stratigraphy of Børglum Elv, Peary Land, eastern North Greenland. Rapp. Grønlands geol. Unders. 82, 48 pp.

Cowie, J. W. 1971: The Cambrian of the North American Arctic Regions. In Holland, C. H. (edit.) Cambrian of the New World 325-383. London: Interscience.

Dawes, P. R. 1976: Reconnaissance of Eocambrian and Lower Palaeozoic strata in south-western Peary Land, North Greenland. Rapp. Grønlands geol. Unders. 80, 9-14.

Dawes, P. R. \& Peel, J. S. in press: The northern margin of Greenland from Baffin Bay to the Greenland Sea. In Churkin, M., Nairn, A. E. M. \& Stehli, F. G. (edit.) The Ocean Basins and Margins, 5, Plenum Publ.

Jepsen, H. F. 1971: The Precambrian, Eocambrian and early Palaeozoic stratigraphy of the Jørgen Brønlund Fjord Area, Peary Land, North Greenland. Bull. Grønlands geol. Unders. 96 (also Meddr Grønland 192, 2) $42 \mathrm{pp}$.

Poulsen, V. 1978: The Precambrian-Cambrian boundary in parts of Scandinavia and Greenland. Geol. Mag. 115, 131-136.

Troelsen, J. C. 1949: Contributions to the geology of the area round Jørgen Brønlund Fjord, Peary Land, North Greenland. Meddr Grønland 149, 2, 29 pp.

Yochelson, E. L. \& Peel, J. S. 1975: Ceratopea and the correlation of the Wandel Vally Formation, eastern North Greenland. Rapp. Grønlands geol. Unders. 75, 28-31. 